GA-A16092

SUMMARY

UC-77

\title{
1170-MW(t) HTGR-PS/C PLANT APPLICATION STUDY REPORT: SHALE OIL RECOVERY APPLICATION
}

\author{
by \\ R. RAO and A. T. McMAIN, JR.
}

\begin{abstract}
Prepared under
Contract DE-AT03-76SF70046

for the San Francisco Operations Office

Department of Energy
\end{abstract}

GENERAL ATOMIC PROJECT 6600

DATE PUBLISHED: MAY 1981

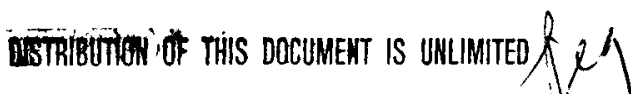

\section{GENERAL ATOMIC COMPANY}




\section{DISCLAIMER}

This report was prepared as an account of work sponsored by an agency of the United States Government. Neither the United States Government nor any agency Thereof, nor any of their employees, makes any warranty, express or implied, or assumes any legal liability or responsibility for the accuracy, completeness, or usefulness of any information, apparatus, product, or process disclosed, or represents that its use would not infringe privately owned rights. Reference herein to any specific commercial product, process, or service by trade name, trademark, manufacturer, or otherwise does not necessarily constitute or imply its endorsement, recommendation, or favoring by the United States Government or any agency thereof. The views and opinions of authors expressed herein do not necessarily state or reflect those of the United States Government or any agency thereof. 


\section{DISCLAIMER}

Portions of this document may be illegible in electronic image products. Images are produced from the best available original document. 
INTRODUCTION

The U.S. has large shale oil energy resources, and many companies have undertaken considerable effort to develop economical means to extract this oil within environmental constraints. The recoverable shale oil reserves in the U.S. amount to $160 \times 10^{9} \mathrm{~m}^{3}\left(1000 \times 10^{9} \mathrm{bb1}\right)$ and are second in quantity only to coal. This report summarizes a study to apply an 1170-MW( $t$ ) hightemperature gas-cooled reactor - process steam/cogeneration (HTGR-PS/C) to a shale oil recovery process. Since the highest potential shale oil reserves lie in the Piceance Basin of Western Colorado, the study centers on exploiting shale oil in this region.

Shale is typically covered by an overburden that makes open pit mining uneconomical. The shale must be retorted to extract combustible fluids; the retorting is done at the mine site, because transporting the shale elsewhere is uneconomical. Above-ground retorting presents several disadvantages, such as large volumes of tailings (larger than the mined volumes due to expansion after retorting) that have to be revegetated, considerable power requirements for extraction and crushing, and severe environmental limitation to prevent atmospheric pollution and contamination to aquifers. These disadvantages all require large amounts of water, not available in arid Western Colorado. In fact, according to an Environmental Protection Agency sponsored study, the Piceance basin production will be 1 imited to 63,560 to $95,340 \mathrm{~m}^{3} /$ day $(400,000$ to $600,000 \mathrm{bpd})$ by water availability if above-ground retorting is adopted.

In-situ retorting is one alternative being investigated. In this approach, shale is fractured underground by blasting, then retorted with air (by igniting the shale underground and flowing air to the fire) or with steam injected at sufficient temperatures $\left[427^{\circ}\right.$ to $538^{\circ} \mathrm{C}\left(800^{\circ}\right.$ to $\left.\left.1000^{\circ} \mathrm{F}\right)\right]$ to extract the combustible fluids. Controlling underground combustion, 
ensuring complete collection of valuable combustion products, and preventing aquifer contamination are difficult with air retorting. Steam retorting allows better emission control and improves the quality of the shale oil produced. It is particularly appropriate for shales that have a natural porosity. The recovery pattern is similar to that of in-situ heavy oil recovery with steam.

Shale oil extraction processes are still being investigated. Accordingly, this study is necessarily preliminary. It is based on in-situ steam retorting, which appears to be potentially attractive. The HTGR is highly suitable as a steam source for this process, while light water reactors (LWRs) are unsuitable, because they produce steam at temperatures too low for shale retorting.

\section{APPLICATION REQUIREMENTS}

This study is based on the Equity 0il Company in-situ steam retorting project, located in Piceance Basin shale fields having a good natural porosity. A pilot plant is being operated within these fields, injecting steam at $10.34 \mathrm{MPa}(1500 \mathrm{psia})$ and $538^{\circ} \mathrm{C}\left(1000^{\circ} \mathrm{F}\right)$. For the HTGR application, a five-spot, $0.8-\mathrm{m}^{2}$ (2-acre) square pattern of oil recovery wells is proposed with a centrally located steam injection well (see Fig. 1). Steam is to be injected continuously at $17.0 \mathrm{~kg} / \mathrm{s}\left(1.25 \times 10^{5} \mathrm{lb} / \mathrm{hr}\right)$ through each injection we11. The steam is injected over the $16.2-\mathrm{m}^{2}$ (40-acre) area, and an oil liberation of $5182 \mathrm{~m}^{3} /$ day $(32,600 \mathrm{bpd})$ is expected. This yield represents $50 \%$ of the in-place reserve. Since the Piceance Basin is a remote area, the reactor can be located relatively close to the well heads, and pressure drops and steam losses in the steam lines are expected to be modest. No reboiler has been included to isolate the injected steam from the secondary coolant loop of the reactor. A reboiler may be included, if deemed necessary, but it would modestly reduce performance, primarily reducing output of cogenerated electrical power. 


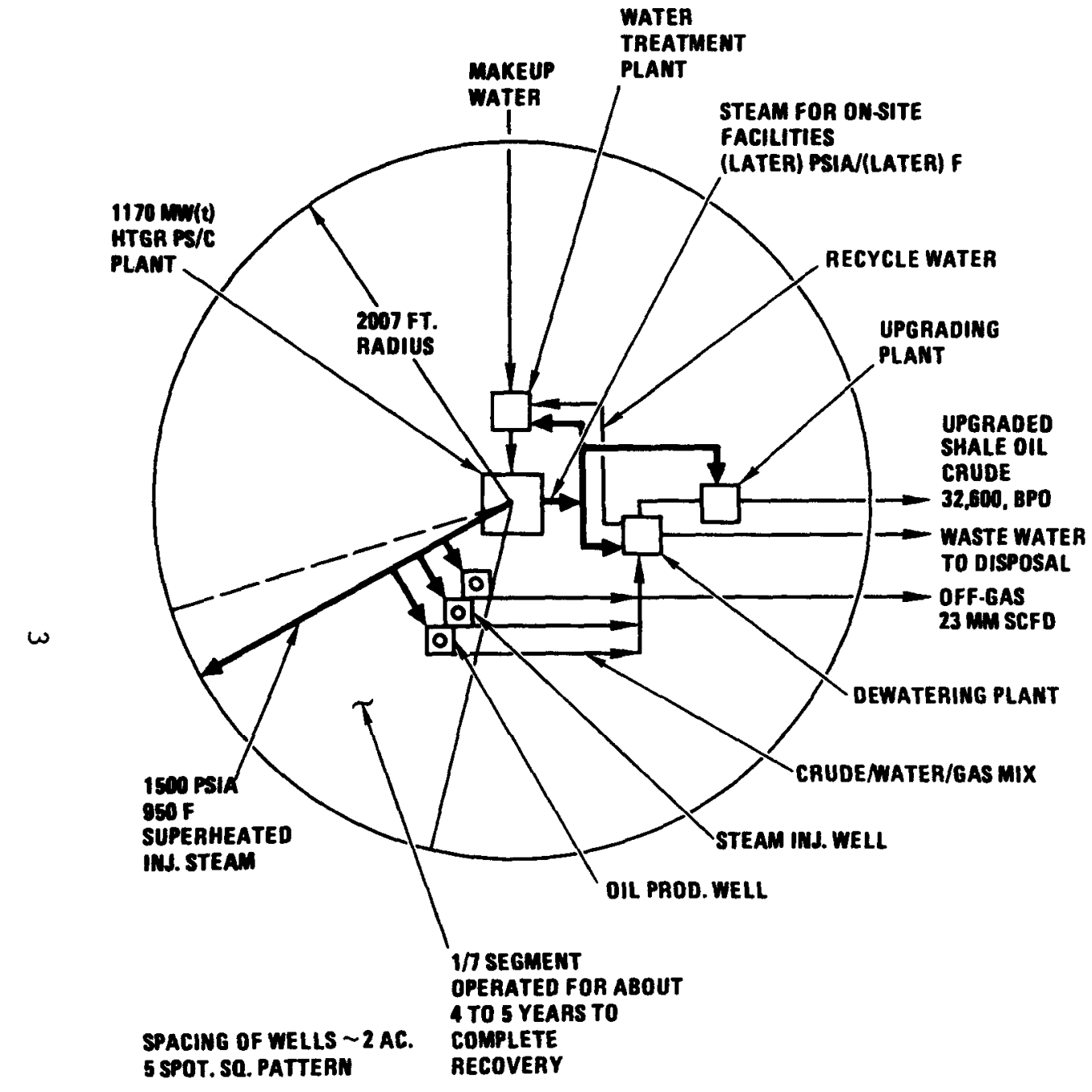

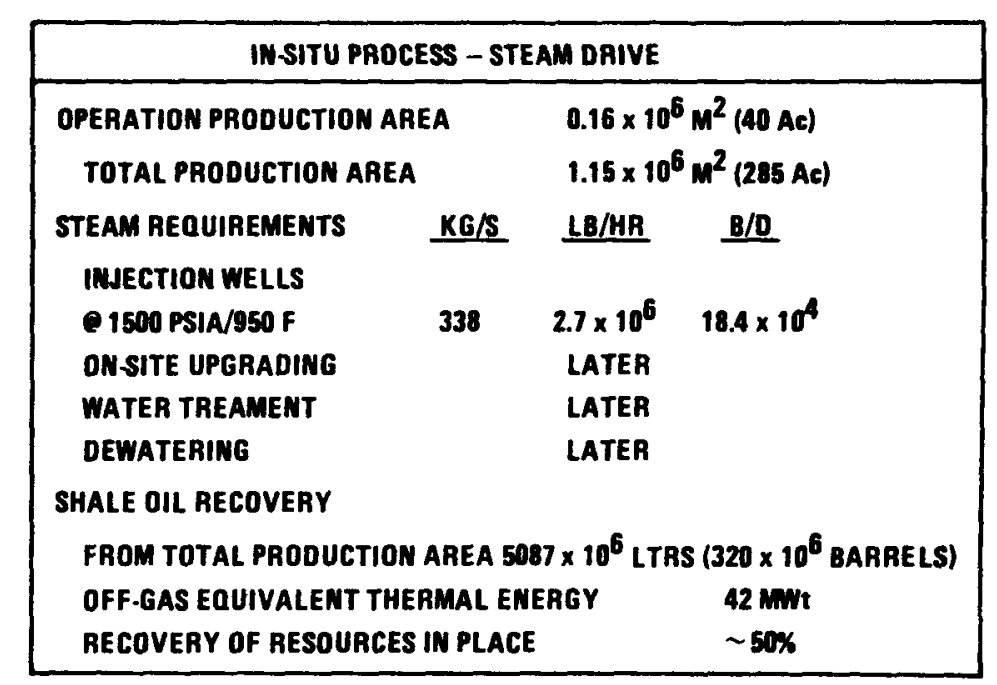

Fig. 1. Field arrangement for $5173 \mathrm{~m}^{3}(32,600$ barrel) per stream day oil shale recovery application using an 1170-MW( $(t)$ HTGR-PS/C 
The selected heat cycle (see Fig. 2) is designed to produce as much steam as possible to recover shale oil. No specific electric power requirements are established for the recovery process at this time, but they are assumed to be small in the absence of any immediate product upgrading plant. Only enough steam to provide extraction steam for feedwater heating is supplied to the turbine generator. The feedwater train includes three heaters plus a deaerating heater. The turbine is a noncondensing unit expanding from $16.65 \mathrm{MPa}$ (2415 psia) to $58 \mathrm{kPa}$ ( $8.42 \mathrm{psia}$ ), similar to the highpressure and intermediate-pressure units of a small conventional turbine generator. The turbine flow is $146 \mathrm{~kg} / \mathrm{s}\left(1.16 \times 10^{6} \mathrm{lb} / \mathrm{hr}\right)$, while the steam flow generated by the $1170-M W(t)$ HTGR-PS/C is $483 \mathrm{~kg} / \mathrm{s}\left(3.83 \times 10^{6} \mathrm{lb} / \mathrm{hr}\right)$; the remaining $337 \mathrm{~kg} / \mathrm{s}\left(2.67 \times 10^{6} \mathrm{lb} / \mathrm{hr}\right)$, representing an output of 1091 MW, are used for injection, after throttling down to the injection pressure of $10.34 \mathrm{MPa}(1500 \mathrm{psia})$. The steam temperatures are $538^{\circ} \mathrm{C}\left(1000^{\circ} \mathrm{F}\right)$ at the HTGR outlet and about $510^{\circ} \mathrm{C}\left(915^{\circ} \mathrm{F}\right)$ at the injection wells. The return flow of condensate and makeup from the shale oil recovery process is assumed to be at $124 \mathrm{kPa}(180 \mathrm{psia})$ and $38^{\circ} \mathrm{C}\left(100^{\circ} \mathrm{F}\right)$. This flow is passed through a full flow demineralizer. The electrical generator output is $99.3 \mathrm{MW}(\mathrm{e})$, while the net output is $63.3 \mathrm{MW}(\mathrm{e})$. The difference is used to drive the HTGR circulators, the feedpumps, and other nonprocess auxiliaries.

A coal-fired cycle, having a steam output of the same magnitude as the 1170-MW( $(t)$ HTGR, was studied for comparison. As indicated by Fig. 3, this cycle is very similar to the previous one, except for the heat source. The coal-fired plant delivers the same supply of steam to the shale oil field, but it requires a higher overall thermal rating [1230.2 instead of 1170 $\mathrm{MW}(t)$ ] and produces more electric power [69.5 instead of $63.3 \mathrm{MW}(\mathrm{e})]$.

0il shale processes, as presently formulated, provide most of their own energy requirement through an intermediate product, a low-caloric combustible off-gas. To make the HTGR application attractive, the process should be modified to utilize this off-gas economically. Upgrading the gas to make it marketable appears difficult considering the large shipping distances involved. An attractive alternate could involve upgrading the shale oil to 


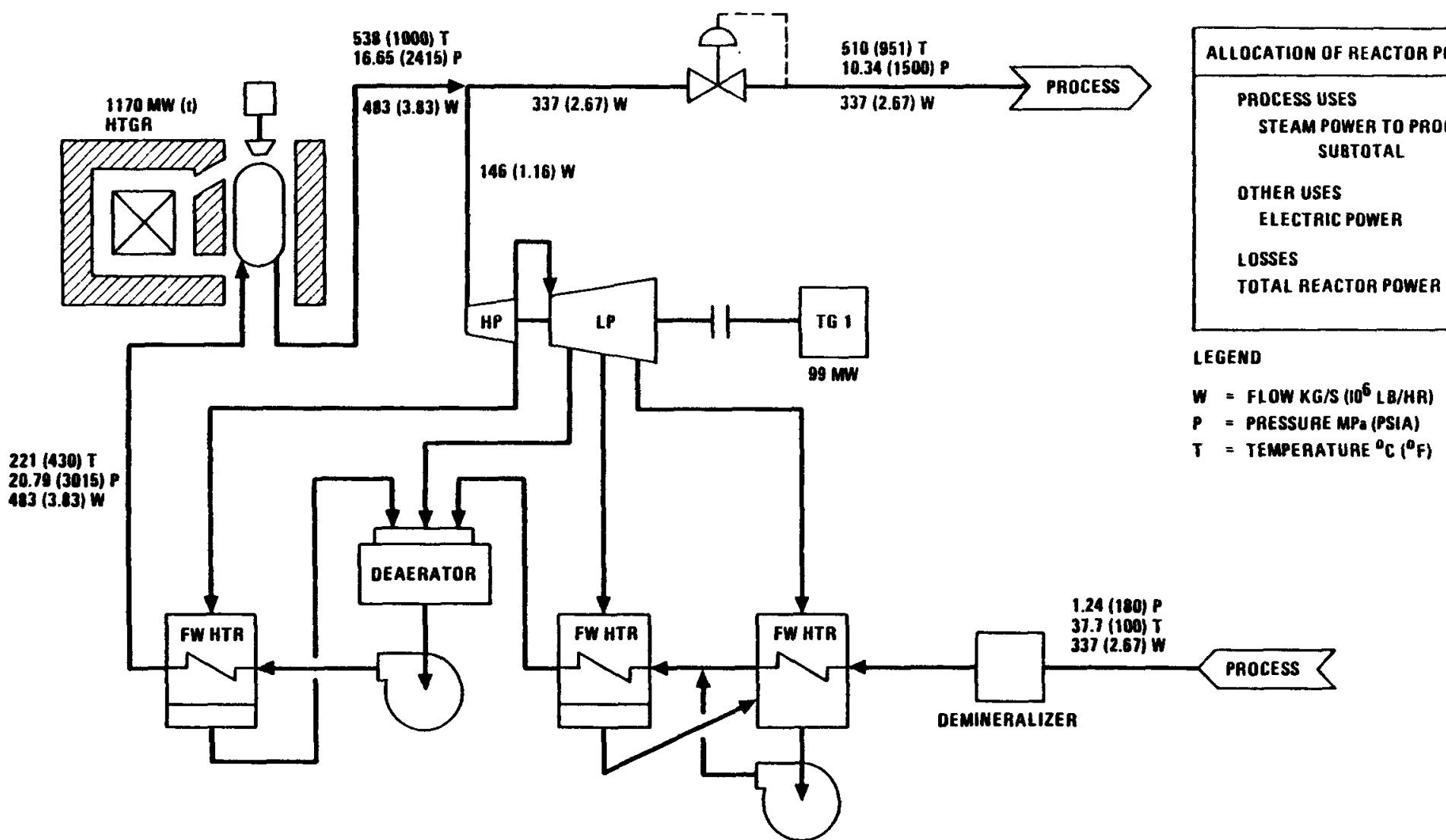

C011-E027

Fig. 2. Cycle diagram for an $1170-M W(t)$ HTGR-PS/C plant for $5173 \mathrm{~m}^{3}(32,600$ barre1) per stream day oil shale recovery application 


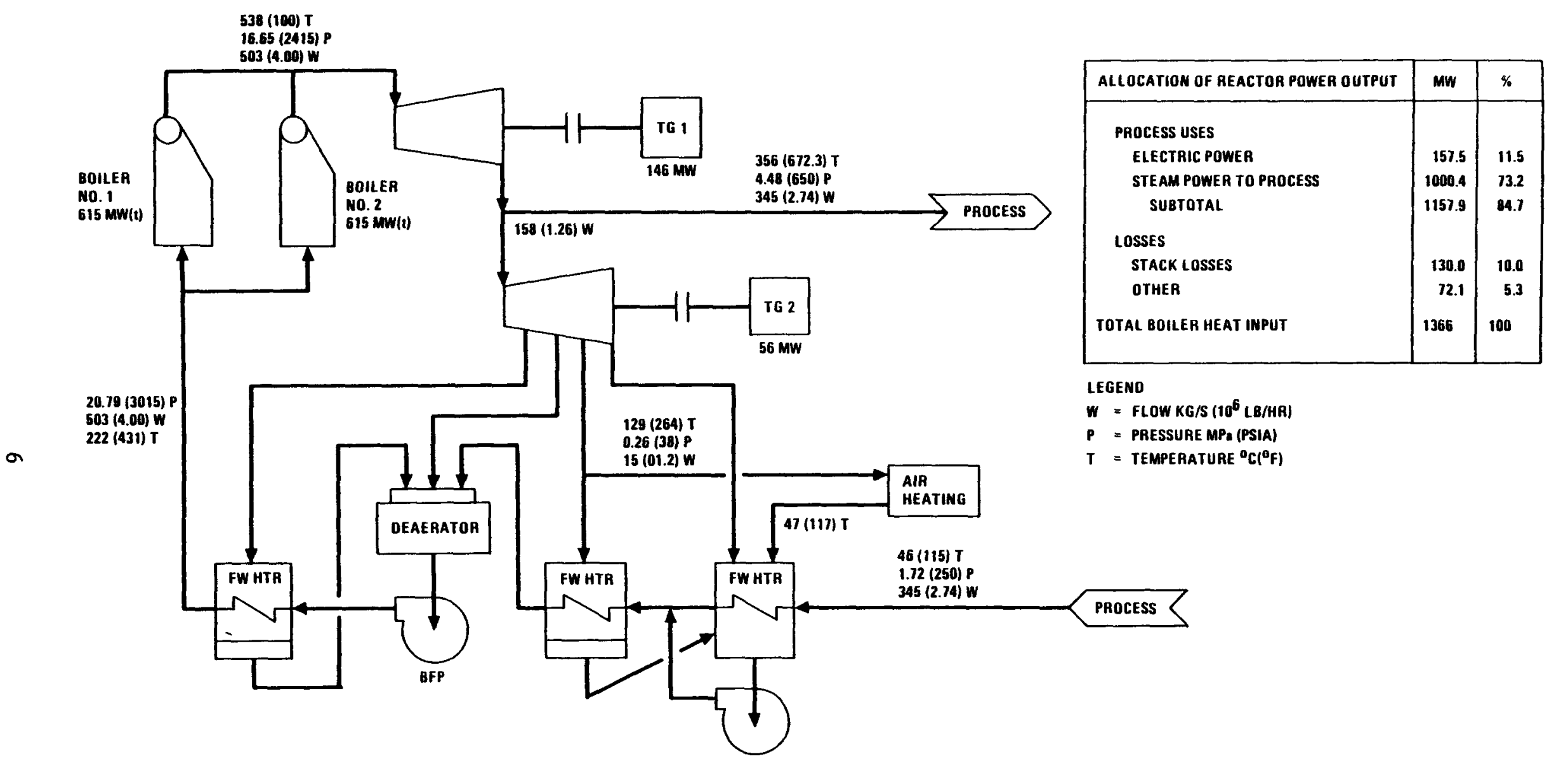

C012-E036

Fig. 3. Cycle diagram for a coal-fired PS/C plant for multipurpose applications 
reduce its waxiness, improve its viscosity and pour point, and make it suitable for feeding to conventional refineries presently using light crude as feedstock. A further merit of the latter approach is that the combustible off-gases may be a backup energy supply for the injection steam generator so that shale oil recovery and upgrading may continue when the reactor is shut down for maintenance and repairs, including refueling.

\section{ECONOMIC ANALYSIS}

The revenue requirement method was selected to evaluate alternative projects. This technique is appropriate for evaluating 1 ong-1ived coal and nuclear cogeneration power plant projects. It determines the revenue needed by the firm as compensation for all fixed and variable expenditures. Hence, the revenue requirements of the firm equal the consumer cost for the process steam cogenerated.

Table 1 compares estimated energy costs of the 1170-MW( $t$ ) HTGR-PS/C versus the comparable coal-fired PS/C plant for shale oil recovery. It shows a clear advantage ( $28 \%$ less cost to deliver energy) of the HTGR over a coal-fired plant.

This analysis is based on economic assumptions used to evaluate utility cogeneration projects in progress for the Department of Energy (DOE) by GA in coordination with Gas Cooled Reactor Association (GCRA). Table 2 gives the principal assumptions of the economic analysis, a key one being the $18 \%$ fixed charge rate for capital use/recovery. Such a rate may be higher if industrial ownership ground rules are applied. Therefore, the economics should be determined using the economic ground rules appropriate for the specific application. Industrial user input is being developed regarding possible alternative economic ground rules. 
TABLE 1

ECONOMIC ANALYSIS OF HTGR-PS/C PLANT VERSUS COAL-FIRED PS/C PLANT FOR SHALE OIL RECOVERY APPLICATION

\begin{tabular}{|c|c|c|}
\hline & $\begin{array}{l}\text { HTGR-PS /C } \\
\text { P1ant }\end{array}$ & $\begin{array}{l}\text { Coal-Fired } \\
\text { P1ant }\end{array}$ \\
\hline Heat input to cycle (MW) & 1170.0 & 1230.2 \\
\hline Heat output in process steam (MW) & 1090.9 & 1090.9 \\
\hline Net electrical power output (MW) & 63.3 & 69.5 \\
\hline Capital Costs $\left(\$ \times 10^{6}\right)$ & & \\
\hline Base capital cost $(1 / 80 \$)$ & 536 & 358 \\
\hline Escalation through construction & 535 & 405 \\
\hline Interest during construction & 336 & 152 \\
\hline Total capital cost (1/95\$) & $\overline{1407}$ & $\overline{915}$ \\
\hline Annua1 Costs ( $\$ \times 10^{6} /$ year) (a) & & \\
\hline Fixed charges & 253 & 165 \\
\hline Fuel costs & 81 & 229 \\
\hline O\&M costs & 63 & 69 \\
\hline Credit for electric power & $(66)$ & $(72)$ \\
\hline Total annual costs & 331 & 461 \\
\hline $\begin{array}{l}\text { Process Steam Cost } \\
{[\mathrm{mills} / \mathrm{kW}(\mathrm{t})-\mathrm{hr}(\$ / \mathrm{MMBt})]}\end{array}$ & $49.5(14.51)$ & $68.8(20.18)$ \\
\hline $\begin{array}{l}\text { Ratio of Energy Cost to Cost } \\
\text { with HTGR-PS/C }\end{array}$ & -- & 1.4 \\
\hline
\end{tabular}

(a) $1 / 95 \$$ levelized over a 30 -year period. 
TABLE 2

ECONOMIC ANALYSIS ASSUMPTIONS

\begin{tabular}{|c|c|}
\hline Commercial operation of all plants: & $1 / 1 / 95$ \\
\hline Capacity factor: & $70 \%$ \\
\hline Levelizing period: & 30 years \\
\hline Electric power credit: & $22 \mathrm{mills} / \mathrm{kW}-\mathrm{hr}(80 \mathrm{\$})$ \\
\hline Discount rate: & $10 \% /$ year \\
\hline Fixed charge rate: & $18 \% /$ year \\
\hline Interest during construction: & $10 \% /$ year (simple interest) \\
\hline Coal cost escalation: & $8 \% /$ year \\
\hline Fuel oil escalation: & $9 \% /$ year \\
\hline A11 other escalation: & $6 \% /$ year \\
\hline Construction period: & $\begin{array}{l}6 \text { years for all plants } \\
\text { ( } 2 \text { years for No. } 6 \text { oil- } \\
\text { fired plants) }\end{array}$ \\
\hline $\mathrm{U}_{3} \mathrm{O}_{8}$ (yellowcake) cost: & $\begin{array}{l}\$ 121 / \mathrm{kg}(\$ 55 / 1 \mathrm{~b}) \text { in } 1990, \\
\text { rising to } \$ 264 / \mathrm{kg}(\$ 120 / \\
\text { lb) in } 2030\end{array}$ \\
\hline Separative work unit (SWU) cost: & $\$ 100 / \mathrm{kg}-\mathrm{SWU}(80 \$)$ \\
\hline Tails assay: & $0.2 \%$ \\
\hline Coal cost: & $\begin{array}{l}4.64 \mathrm{mills} / \mathrm{kW}-\mathrm{hr}(\$ 1.36 / \\
\text { MMBtu })(80 \$)\end{array}$ \\
\hline No. 2 oil cost: & $\begin{array}{l}18.2 \mathrm{mills} / \mathrm{kW}-\mathrm{hr}(\$ 5.33 / \\
\text { MMBtu })(80 \$)\end{array}$ \\
\hline No. 6 oil cost: & $\begin{array}{l}13.5 \mathrm{mi} 11 \mathrm{~s} / \mathrm{kW}-\mathrm{hr}(\$ 3.95 / \\
\text { MMBtu })(80 \$)\end{array}$ \\
\hline $\begin{array}{l}\text { HTGR-PS/C fuel cycle cost } \\
\text { (includes recycle): }\end{array}$ & $\begin{array}{l}11.23 \mathrm{mil} 1 \mathrm{~s} / \mathrm{kW}-\mathrm{hr}(\$ 3.29 / \\
\text { MMBtu }(1 / 95 \$ \text { levelized } \\
\text { over } 30 \text { years) }\end{array}$ \\
\hline
\end{tabular}


Ultimately, the economic analysis method will be determined by the nuclear cogeneration plant ownership:

1. Industrial ownership with connection to the utility grid for backup electric power and sale of excess power (per recent Federal Energy Regulatory Commission rulings regarding a more favorable arrangement for industry).

2. Utility ownership with both steam and cogenerated electric power sold to nearby industry.

3. Consortia ownership and sale of energy to industry and local utilities .

The analysis compares the cost of process steam produced by the HTGRPS/C with that produced by a coal-fired cogenerating plant and with the cost of burning No. 2 oil in existing equipment. It includes a credit for the electric power produced by the HTGR and coal-fired cogenerating plants. The analysis indicates a clear advantage for the HTGR over the coal and oil alternatives.

The assumed fuel cost for coal will also vary according to site location and other factors (i.e., Eastern versus Western coal, mine-mouth locations, etc.).

The most competitive oil shale application for the HTGR-PS/C is through an in-situ injection of high-pressure, high-temperature steam for shales with high permeability. These shales represent $\sim 8 \%$ to $10 \%$ of the total resource in the Piceance Basin of Colorado. Assuming that up to half of the foreseen $63,560 \mathrm{~m}^{3} /$ day $(400,000 \mathrm{bpd})$ potential could be captured by the HTGR and considering that each 1170-MW(t) HTGR can provide steam for $\sim 5164$ $\mathrm{m}^{3} /$ day $(\sim 32,500 \mathrm{bpd})$, a market exists for about six such HTGR units in this area of Western Colorado. The market might be enlarged by applying the HTGR to oil shales in other locations. However, depending upon shale recovery as 
an important vehicle for developing the HTGR-PS/C is risky. The optimum recovery process is simply not well enough defined. The alternatives of insitu or open-air operation and steam or combustion retorting remain to be resolved. Further, since economics and regulatory restrictions are uncertain, the commercialization of shale oil recovery is not assured. Thus, a significant application development risk remains. 